\title{
1 One more avenue for whale-watching contributions to science: the study of
}

\section{2 cetacean-cephalopod interactions}

3 STÉPHANIE R.A. SUCIU, JASMINE ZEREBA, LORENZO FIORI AND JOSÉ M.N.

\section{AZEVEDO}

\section{Abstract}

6 Cephalopods are the primary source of food for several species of odontocetes. The unstable

7 nature of this trophic resource is likely to affect the ecology of their cetacean predators, and

8 this can be reflected on their conservation status but also on the tourist activities which target

9 the observation of these animals. However, the study of the cetacean-cephalopod interaction is

10 limited by the heavy logistics and expense of dedicated scientific campaigns. Fortunately, this

11 gap can be filled by coupling modern molecular tools with indirect sampling methods. In this

12 note we test if whale watching activities, which represent an intense observation effort

13 worldwide, could be a source of material for studies of cetacean-cephalopod interactions. All

14 contacted companies welcomed the invitation and received the sampling kit. Nine samples were collected, most of them in close association with sperm whales. All samples were determined as the seven-arm octopus Haliphron atlanticus (Octopoda, Alloposidae). We conclude that, although the Azores may have particularly favorable conditions for participatory science, similar programs can be replicated elsewhere

19 Keywords: cephalopods, DNA barcoding, teuthophagous cetaceans, whale watching, participatory science

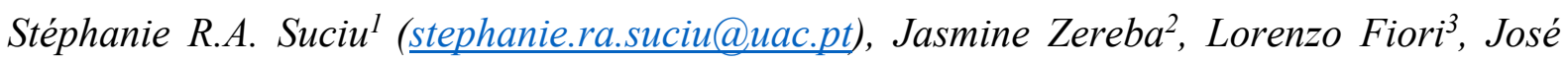
M.N. Azevedo'. 'Azorean Biodiversity Group (University of the Azores), Centre for Ecology, Evolution and Environmental Changes (CE3C), Rua da Mãe de Deus, 9500-321 Ponta 
26 Cephalopods have a structuring role in oceanic ecosystems, acting as a link between different trophic levels by feeding on a variety of fish and invertebrates and being in turn eaten by a wide range of predators including fish, sharks, marine mammals and seabirds (de la Chenais et al., 2019; Escánez et al., 2020). The short life span of most species accounts for variable population sizes over time, their population dynamics tracking environmental conditions, such as food abundance or water temperature (Forsythe, 2004; Jackson and Moltschaniwskyj, 2002). The resulting variability in cephalopod biomass can directly affect the biomass of their prey and can also influence their predators, including marine mammals (Liu \& Chen, 2009). The unstable population dynamics of oceanic cephalopods is likely to be a key factor influencing the distribution of teuthophagous cetaceans, with effects on conservation but also economic given the importance of whale watching (O'Connor et al., 2019).

Because cephalopod habitats, behaviors, morphology and life-history strategies vary so greatly, a single standard approach does not suffice. Direct sampling methods include trawling and video-surveys (Hoving et al., 2014). However, each of these has its own biases. The sophisticated features associated with the predatory behavior of cephalopods such as vision and agility, for example, may result in avoidance behavior towards many types of oceanographic gears (Villanueva et al., 2017). On the other hand, even specimens captured in trawled nets may be damaged, making their morphological identification challenging

44 (Vecchione et al., 2010).

An indirect method of studying cephalopods and determining their presence in a region, is by analysis of remains found in the stomach content of their predators (Clarke et al., 1993). Being crucial to look at cetacean diet, this method has limitations for studying cephalopod ecology, stemming from predator selectivity and unprecise location data. Even so, it has been claimed that stomach content analysis provides a better overview of cephalopod distribution and relative abundance than net catches (Clarke, 2006). However (and fortunately) research on 
51 cetacean diet from stomach contents almost stopped with the 1980's IWC moratorium on whale hunting. Some of the methodological, logistic, and ethical limitations to sampling pelagic cephalopods can nevertheless be overcome with molecular approaches (O'Brien et al., 2018). DNA barcoding, for instance, allows individual species identification based on an organism's remains but also to determine community composition from DNA fragments persisting in environmental samples, such as water (Valentini et al., 2009). Using these methods, species can be determined from damaged samples captured by commercial nets (e.g. Dai et al., 2012), and partially digested remains from seabirds, fishes, stranded whales and seals stomachs

59 (Hoving et al., 2014; Xavier et al., 2015).

60 Cephalopod remains are occasionally observed at the surface in connection with cetacean 61 feeding activities (Fig. 1), and they have been used inconsistently as a source of information on deep water cephalopods (Clarke, 1996c). We could not find publications using this material, which is not surprising because of its unpredictable source which, to be systematically collected, would require an intense and targeted effort, not compatible with the standards of regular scientific work. Nevertheless, we did find references to the observation of cephalopod remains in the context of whale watching activities (Escanez et al. 2019; Sarabia-Hierro \& Rodriguéz-González, 2019). Whale watching is an important tourist industry worldwide, and it represents a huge observation effort in terms of number of boats, miles crossed, and hours spent at sea (O’Connor et al., 2009), unmatched by standard scientific campaigns. Harnessing this effort can provide inexpensive and valuable information about marine life, particularly in data deficient areas. Examples of the scientific use of opportunistic data from whale watching include the study of coastal cetaceans off the southwest coast of South Africa (Vinding et al. 2015) or the analysis of how temporal scales influence cetacean ecological niche modelling (Fernandez et al. 2018). We therefore argue that whale watching operations worldwide, with 
to collect floating cephalopod remains and make them available for scientific purposes. The present paper presents the results of a pilot project set up to test this idea.

The study was carried out in 2020, on São Miguel Island, Azores, where a whale watching industry is operating since the early 1990's (Silva, 2015). All the five companies operating in that year accepted to participate. Each company received a boxed sampling kit, and staff training on the collection of samples and related information. The protocol was simple: every time a vessel would spot cephalopod remains they would collect a piece (including the beak, if present) and preserve it in $96 \%$ ethanol inside the supplied jars. Additionally, they were requested to collect, as a minimum, the time and geographic position, and information about the species of cetaceans in the area and their behavior. If possible, photographs of the remains should also be taken. Upon return to base a contact would be made with the research team which would pick up the samples and store them at $4{ }^{\circ} \mathrm{C}$. The project was cost-free for the companies, and was run on a $300 €$ budget (not including the human resources cost). A transparency and open data policy was implemented from the beginning, with a website (https://moniceph.wixsite.com/home) set up so that the companies and the public could follow

91 the project activities and results.

At the end of the tourist season the samples were sent to an external laboratory which took care of DNA extraction and PCR amplification of the mitochondrial COI gene using the primers jgHCO2198 and jgLCO1490 (Geller et al., 2013). Forward and reverse sequences were assembled using Geneious (v. R10, Biomatters, Auckland, NZ) and reciprocally verified to generate a complete contig of the sequenced fragments. All contigs were compared to the BOLD reference database and the NCBI nucleotide database using the BLAST algorithm also analyzed for morphological species determination. 
100 A total of 9 samples were collected, including some taken the previous year. Information about

101 an additional finding for which a biological sample was not available was also recorded. This

102 information, and the results of the morphological and molecular species determination, are

103 given in Table 1. The seven-arm octopus Haliphron atlanticus (Octopoda, Alloposidae) was

104 the only species identified. On most occasions, sperm whales were present in the area where 105 remains were found. Although Clarke et al. (1993) reported that sperm whales in the Azores 106 feed primarily on Octopoteuthidae, Histioteuthidae and Architeuthidae squids, H. atlanticus is 107 also part of this specie's diet (see, recently, Cherel et al., 2021). Common dolphins were 108 associated with the two samples without the presence of sperm whales.

109 The opportunistic nature of samples collected in this manner is likely to introduce bias. The

110 fact that only samples of $H$. atlanticus were collected could, for instance, be due to the "watery"

111 nature of this species, with the predator focusing mainly on the buccal mass and rejecting the

112 rest, as speculated by Santos et al. (2001) for blue sharks. Carried out consistently across time

113 and space a monitoring program such as the one presented here could clarify these biases while

114 providing relevant information on issues like changes in relative abundance of oceanic

115 cephalopods or the diet of their cetacean predators.

116 In summary, our results show that, by collecting remains of cephalopods associated with

117 cetacean observations, whale watching companies can contribute to fill a gap in indirect

118 research on cephalopod ecology and cephalopod-cetacean interactions.

119 In our experience, companies showed immediate interest for the project and have expressed

120 their willingness to continue collaborating with it. We believe this attitude is based on the low

121 cost of this collaboration compared to its perceived added value, not only to the marketing

122 image of the company (resulting from being associated with research activities) but also to the

123 improvement of client experience. This is in line with the results of Bentz et al. (2016) which

124 demonstrate that whale watchers in the Azores value receiving information about the cetaceans 
and their environment. But another important factor was the motivation demonstrated by the

126 tour guides which, for the most part, had degrees on biological sciences because this is a legal

127 requirement. Thus, it may be that the institutional conditions in the Azores are favorable to the

128 engagement of the industry with participatory science (e.g. Philips et al., 2019; Wuebben et al.,

129 2020). In retrospect, however, we seem to have followed most of the engagement framework

130 laid out by Pandya (2012): our request was aligned with community priorities, we built on

131 existing knowledge and validated previous practices and we made a point of disseminating the

132 results widely, so that effort was recognized. We therefore believe that our results are replicable

133 elsewhere, and encourage the establishment of communities of practice between members of

134 the whale watching and the research communities, in order to take full advantage of this

135 research opportunity.

136

\section{Acknowledgements}

138 We appreciate the positive and encouraging response obtained from the managers and staff of

139 the whale watching companies participating on this pilot project: Sea Colors Expeditions, Terra

140 Azul, Futurismo, Moby Dick, Picos de Aventura. We thank

141 Jasmine Zereba, Lorenzo Fiori, Marylou Féat, Mariana Silva, Ana Castanheira and Vanessa

142 Costa for collecting the samples while operating whale watching activities.

\section{References}

145 Bentz, J., F. Lopes, H. Calado and P. Dearden 2016. Managing marine wildlife tourism 146 activities: Analysis of motivations and specialization levels of divers and whale watchers,

147 Tourism Management Perspectives 18: 74-83. https:// doi.org/10.1016/j.tmp.2016.01.004 
148 Cherel, Y. 2021. Revisiting taxonomy of cephalopod prey of sperm whales caught

149 commercially in subtropical and Southern Ocean waters. Deep Sea Research Part I:

150 Oceanographic Research Papers 103490. https://doi.org/10.1016/j.dsr.2021.103490

151 Clarke, M., H. Martins and P. Pascoe, P. 1993. The Diet of Sperm Whales (Physeter 152 macrocephalus Linnaeus 1758) off the Azores. Philosophical transactions of the Royal Society of London B, Biological sciences 339: 67-82. http://doi.org/10.1098/rstb.1993.0005

154 Clarke, M.R. 1996c. Cephalopods as prey. III. Cetaceans. Philosophical Transactions of the Royal Society of London B 3511053-1065. https://doi.org/10.1098/rstb.1996.0093

156 Clarke, M.R. 2006. Oceanic cephalopod distribution and species diversity in the eastern north

157 Atlantic. Arquipélago. Life and Marine Sciences 23A: 27-46.

158 Clarke, M.R., H. Martins and P.L. Pascoe 1993. The diet of sperm whales (Physeter macrocephalus Linnaeus 1758) off the Azores. Philosophical Transactions of the Royal Society of London B 339: 67-82. https://doi.org/10.1098/rstb.1993.0005

161 Dai, L., X. Zheng, L. Kong and Q. Li 2012. DNA barcoding analysis of Coleoidea (Mollusca: 162 cephalopoda) from Chinese waters. Molecular Ecology Resources 12 (3) : 437-447.

163 de la Chesnais, T., E.A. Fulton and S.R. Tracey 2019. The ecological role of cephalopods and 164 their representation in ecosystem models. Reviews in Fish Biology and Fisheries 29: 313-334. https://doi.org/10.1007/s11160-019-09554-2

166 Escánez, A., A. Guerra, R. Riera and F. Rocha 2010. Revised species records reveal the Canary

167 Islands as a cephalopod biodiversity hotspot. Regional Studies in Marine Science 41.

168 https://doi.org/10.1016/j.rsma.2020.101541

169 Forsythe, J. 2004. Accounting for the effect of temperature on squid growth in nature: from

170 hypothesis to practice. Marine \& Freshwater Research 55: 331-339.

171 https://doi.org/10.1071/MF03146 
172 Geller, J., C.P. Meyer, M. Parker and H. Hawk 2013. Redesign of PCR primers for

173 mitochondrial Cytochrome c oxidase subunit I for marine invertebrates and application in all-

174 taxa biotic surveys. Molecular Ecology Resources 13(5). https://doi.org/10.1111/1755-

$175 \quad 0998.12138$

176 Hoving, H.J., J.A. Perez, K.S. Bolstad, H.E. Braid, A.B. Evans, D. Fuchs, H. Judkins, J.T.

177 Kelly, J.E. Marian, R. Nakajima, U. Piatkowski, A. Reid, M. Vecchione and J.C. Xavier 2014.

178 Chapter three: the study of deep-sea cephalopods. Pp 235-359 in: Vidal, E.A.G. (Eds).

179 Advances in Cephalopod Science: Biology, Ecology, Cultivation and Fisheries. Advances in

180 Marine Biology 67. Academic Press. https://doi.org/10.1016/B978-0-12-800287-2.00003-2

181 Jackson, G. and N. Moltschaniwskyj 2002. Spatial and temporal variation in growth rates and

182 maturity in the Indo-Pacific squid Sepioteuthis lessoniana (Cephalopoda: Loliginidae). Marine

183 Biology 140: 747-754. http://doi.org/10.1007/s00227-001-0746-9

184 Liu, B.L. and Chen, X.J. 2009. Review on the research development of beaks in Cephalopoda.

185 Journal of Fisheries of China 33 (1): 157-164 (in Chinese with English abstract)

186 O'Brien, C.E., K. Roumbedakis and I.E. Winkelmann 2018. The current state of cephalopod

187 science and perspectives on the most critical challenges ahead from three early-career

188 researchers. Frontiers in Physiology 9: 700. https://doi.org/10.3389/fphys.2018.00700

189 O’Connor, S., R., H. Campbell, H. Cortez and T. Knowles 2009. Whale Watching Worldwide:

190 tourism numbers, expenditures and expanding economic benefits. A special report from the

191 International Fund for Animal Welfare, Yarmouth MA, USA, prepared by Economists at

192 Large. $295 \mathrm{pp}$.

193 Pandya, R. E. 2012. A framework for engaging diverse communities in citizen science in the

194 US. Frontiers in Ecology and the Environment 10(6): 314-317. https://doi:10.2307/41811397 
195 Phillips, T. B., H.L. Ballard, B.V. Lewenstein and R. Bonney 2019. Engagement in science

196 through citizen science: Moving beyond data collection. Science Education 103(3): 665-690.

197 https://doi.org/10.1002/sce.21501

198 Santos, M. B., M.R. Clarke and G.J. Pierce 2001. Assessing the importance of cephalopods in

199 the diets of marine mammals and other top predators: problems and solutions. Fisheries

200 Research 52(1-2): 121-139. http://doi.org/10.1016/S0165-7836(01)00236-3

201 Sarabia-Hierro, A. and M. Rodríguez-González 2019. Population parameters on Risso's

202 dolphin (Grampus griseus) in Fuerteventura, Canary Islands. Scientia Insularum. Revista de

203 Ciencias Naturales en islas 2. https://doi.org/10.25145/j.Si.2019.02.02

204 Silva, L. 2015. How ecotourism works at the community-level: the case of whale-watching in

205 the Azores. Current Issues in Tourism 18(3): 196-211.

206 https://doi.org/10.1080/13683500.2013.786027

207 Valentini, A., F. Pompanon and P. Taberlet 2009. DNA barcoding for ecologists. Trends in 208 ecology \& evolution 24: 110-7. https://doi.org/10.1016/j.tree.2008.09.011

209 Villanueva, R., V. Perricone and G. Fiorito 2017. Cephalopods as predators: a short journey

210 among behavioral flexibilities, adaptions, and feeding habits. Frontiers in Physiology 8: 598.

211 https://doi.org/10.3389/fphys.2017.00598

212 Vinding, K., M. Bester, S.P. Kirkman, W. Chivell and S.H. Elwen 2015. The use of data from 213 a platform of opportunity (whale watching) to study coastal cetaceans on the southwest coast

214 of South Africa. Tourism in Marine Environments 11(1): 33-54.

215 https://doi.org/10.3727/154427315X14398263718439

216 Vecchione M., R.E. Young and U. Piatkowski 2010. Cephalopods of the northern Mid-Atlantic

217 Ridge. Marine Biology Research 6: 25-52. https://doi:10.1080/ 17451000902810751 
218 Wuebben, D., J. Romero-Luis and M. Gértrudix 2020. Citizen Science and Citizen Energy

219 Communities: A systematic review and potential alliances for SDGs. Sustainability 12: 10096.

220 https://doi.org/10.3390/su122310096

221 Xavier, J., A. Allcock, Y. Cherel, M. Lipinski, G Pierce, P. Rodhouse, R. Rosa, E. Shea, J.M.

222 Strugnell, E. Vidal, R. Villanueva and A. Ziegler 2015. Future challenges in cephalopod 223 research. Journal of the Marine Biological Association of the UK 95: 999-1015. .

224 https://10.1017/S0025315414000782.

\section{Table and figure}

226 Table 1. Cephalopod samples collected, associated information and species determination by

227 DNA barcoding and image analysis, except where otherwise stated.

\begin{tabular}{|c|c|c|c|c|c|c|c|}
\hline & & & & & & Cetaceans in the & \\
\hline Date & \# & Company & Latitude & Longitude & Depth (m) & area & Cephalopod species \\
\hline $09 / 06 / 19$ & 0 & Terra Azul & 37.6774 & -25.3536 & 730 & Sperm whale & $\begin{array}{l}\text { Haliphron } \\
\text { atlanticus* }\end{array}$ \\
\hline $12 / 07 / 19$ & 1 & Sea Colors & 37.60038 & -25.5503 & 741 & Sperm whale & H. atlanticus \\
\hline $13 / 07 / 19$ & 2 & Sea Colors & 37.5781 & -25.5375 & 826 & Sperm whale & H. atlanticus \\
\hline $26 / 08 / 19$ & 3,4 & Sea Colors & 37.5763 & -25.6516 & 1008 & $\begin{array}{l}\text { Sperm whale } \\
\text { Spotted dolphin }\end{array}$ & H. atlanticus \\
\hline $01 / 08 / 20$ & 5 & Terra Azul & 37.51627 & -25.3631 & 1428 & Sperm whale & H. atlanticus \\
\hline $03 / 08 / 20$ & 6 & Futurismo & 37.6112 & -25.6264 & 786 & $\begin{array}{l}\text { Risso's dolphin } \\
\text { Bottlenose dolphin }\end{array}$ & H. atlanticus \\
\hline $10 / 08 / 20$ & 7 & $\begin{array}{l}\text { Picos de } \\
\text { Aventura }\end{array}$ & 37.51215 & -25.4503 & 1385 & Common dolphin & H. atlanticus \\
\hline $11 / 08 / 20$ & 8 & Terra Azul & 37.667 & -25.3555 & 846 & Common dolphin & H. atlanticus \\
\hline $11 / 08 / 20$ & 9 & Terra Azul & 37.66087 & -25.3806 & 1151 & Sperm whale & H. atlanticus \\
\hline
\end{tabular}

228 * No DNA material; species determination from photograph, only. 

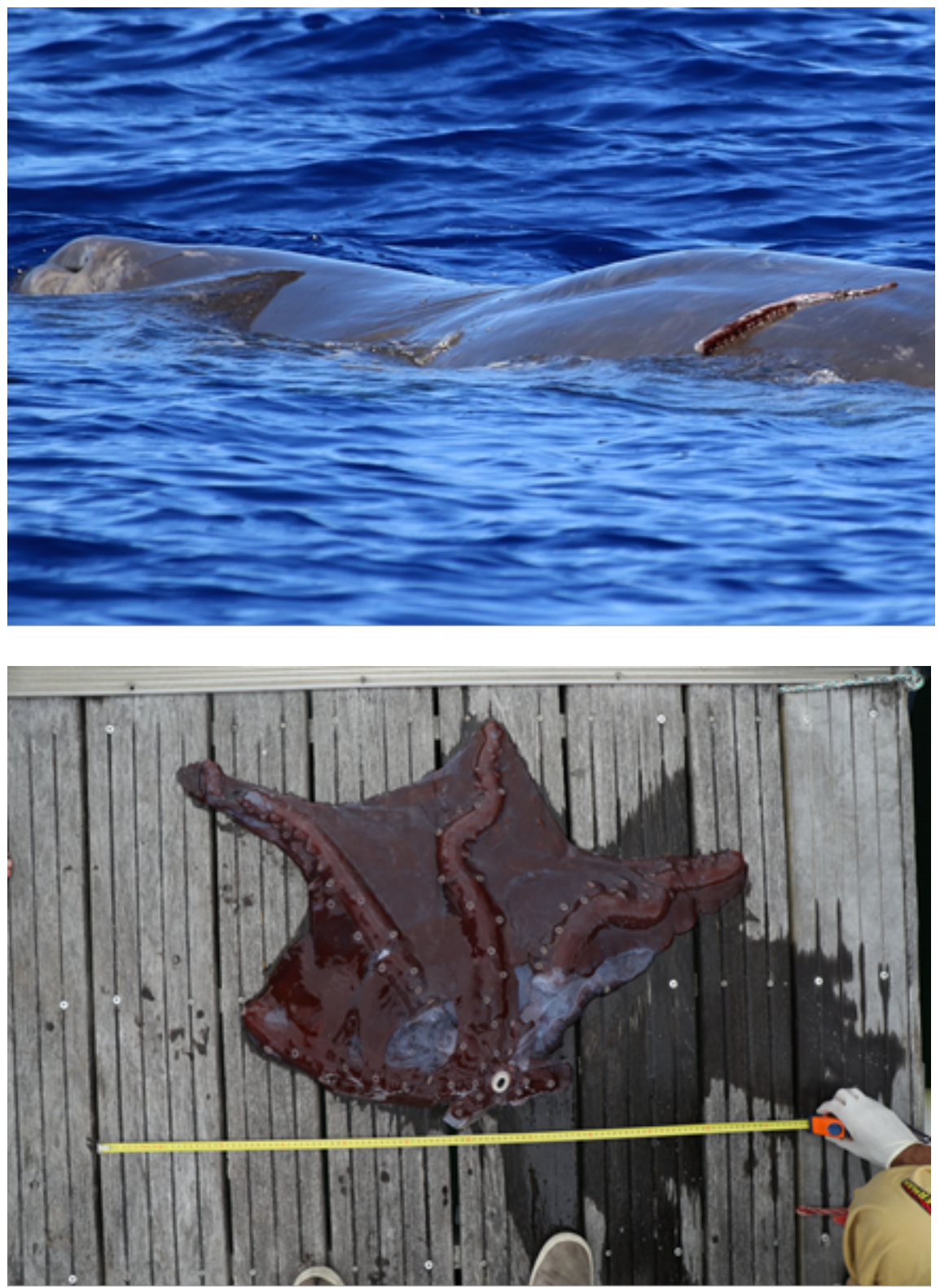

229 Fig. 1. Examples of remains of cephalopods found during whale watching activities. A tentacle

230 on a sperm whale (fig.1(a), credit: Sea Colors Expeditions) and Haliphron atlanticus remains

231 photographed on shore (fig.1(b), credit: Terra Azul) 